\title{
LACCASE PRODUCTION BY LEPISTA SORDIDA
}

\author{
José Renato Pereira Cavallazzi ${ }^{1 *}$; Maria Goreti de Almeida Oliveira $^{2}$; Maria Catarina Megumi Kasuya ${ }^{1}$ \\ ${ }^{1}$ Laboratório de Cogumelos Comestíveis, Departamento de Microbiologia, Universidade Federal de Viçosa, Viçosa, MG, \\ Brasil; ${ }^{2}$ Laboratório de Enzimologia, Departamento de Bioquímica e Biologia Molecular, Universidade Federal de Viçosa, \\ Viçosa, MG, Brasil.
}

Submitted: October 27, 2003; Returned to authors for corrections: January 29, 2004; Approved: June 18, 2004.

\section{SHORT COMMUNICATION}

\begin{abstract}
A Lepista sordida laccase has been characterized. Laccase and manganese peroxidase were detected in liquid medium with ammonium phosphate, yeast extract and ammonium molybdidate as nitrogen sources after 3 days of cultivation. Laccase optimal temperature and $\mathrm{pH}$ were $45^{\circ} \mathrm{C}$ and 3.5 , respectively.
\end{abstract}

Key words: Lepista sordida, laccase, enzyme.

Laccases are oxidases that transfer electrons to dioxygen, yielding water with the concomitant oxidation of a wide range of reducing substrates, including phenolic compounds and aromatic amines. Laccases have been found in many fungi, higher plants and insects $(9,29)$ and are believed to be involved in several microbial and cellular events, such as fungal virulence (22), conidial pigmentation (31), lignification (6) and plant defense (18). However, their most important role is in lignin degradation and humification processes (19). Laccases have been the subject of much research for a broad variety of practical applications because of their low specificity. Some practical applications include: removal of xenobiotics from aqueous streams (4), removal of phenolic compounds from wine (26), biosensors (34), decolorisation of dyes (27) and effluents contaminated with industrial wastes (23), drug analysis (1), ethanol production (14) and removal of lignin from woody tissues (2). The wide range of substrates that can be attacked by laccases has led to a search for new sources of the enzyme $(11,20,21)$. Lepista sordida (Schum.: Fr.) Singer is a basidiomycete fungus that produces an excellent tasting light purple mushroom. It grows in bare locations such as waysides and parks. No information on its laccase activity has yet been reported in the literature, as far as we know. In this study, the production and characterization of a laccase produced by $L$. sordida are presented.

Lepista sordida was isolated from a mushroom found at the campus of Federal University of Viçosa, Minas Gerais State, Brazil. The fungal culture was maintained through periodic transfer onto potato dextrose agar (PDA) plates at $25^{\circ} \mathrm{C}$ and $\mathrm{pH}$ 5.5. Agar disks taken from the active borders of PDA cultures were transferred into $60 \mathrm{~mL}$ of sterile liquid medium $(\mathrm{pH} 5.5)$ containing $\mathrm{CaCl}_{2}\left(0.5 \mathrm{~g} / \mathrm{L} ; \mathrm{MERCK}\right.$, Darmstadt, Germany), $\mathrm{FeCl}_{3}$ (0.0012 g/L; MERCK, Darmstadt, Germany), $\left(\mathrm{NH}_{4}\right)_{2} \mathrm{HPO}_{4}(0.15$ g/L; MERCK, Darmstadt, Germany), NaCl (0.025 g/L; MERCK, Darmstadt, Germany), $\mathrm{KH}_{2} \mathrm{PO}_{4}(0.5 \mathrm{~g} / \mathrm{L}$; SIGMA, MO, USA), $\mathrm{MgSO}_{4} .7 \mathrm{H}_{2} \mathrm{O}(0.15 \mathrm{~g} / \mathrm{L}$; SIGMA, MO, USA), glucose $(2.5 \mathrm{~g} / \mathrm{L}$; SIGMA, MO, USA), yeast extract (0.1 g/L; SIGMA, MO, USA), $\mathrm{MnCl}_{2} .4 \mathrm{H}_{2} \mathrm{O}\left(0.14 \mathrm{~g} / \mathrm{L} ; \mathrm{MERCK}\right.$, Darmstadt, Germany), $\mathrm{H}_{3} \mathrm{BO}_{3}$ $\left(0.118 \mathrm{~g} / \mathrm{L}\right.$; SIGMA, MO, USA), $\mathrm{ZnSO}_{4} .7 \mathrm{H}_{2} \mathrm{O}(0.57 \mathrm{~g} / \mathrm{L}$; MERCK, Darmstadt, Germany) and $\left(\mathrm{NH}_{4}\right)_{6} \mathrm{Mo}_{7} \mathrm{O}_{24} .4 \mathrm{H}_{2} \mathrm{O}(0.011 \mathrm{~g} / \mathrm{L}$; SIGMA, MO, USA). Erlenmeyers flasks ( $125 \mathrm{~mL}$ ) were incubated at $25^{\circ} \mathrm{C}$ in the dark without shaking. Periodically, samples were collected for analysis and the volume of liquid medium withdrawn was replenished from a sterile stock. The liquid cultures were filtered using Millipore membranes $(0.45 \mathrm{~mm})$ and the filtrates were used for enzyme assays. Laccase (EC 1.10.3.2) activity

*Corresponding author. Mailing address: Laboratório de Enzimologia, Departamento de Bioquímica e Biologia Molecular, Universidade Federal de Viçosa. 36571-000, Viçosa, MG, Brasil. Tel: (+5531) 3899-2967. Fax: (+5531) 3899-2573. E-mail: jrpcavallazzi@ hotmail.com 
was determined by the oxidation of 2,2'-azino-bis (3ethylthiazoline-6-sulfonate) (ABTS; SIGMA, MO, USA) at $37^{\circ} \mathrm{C}$ according to Buswell et al. (3). The reaction mixture (1 mL) contained $600 \mu \mathrm{L}$ enzyme extract, $300 \mu \mathrm{L}$ sodium acetate buffer pH 5.0 $(0.1 \mathrm{M})$ and $100 \mu \mathrm{LABTS}$ solution $(1 \mathrm{mM})$. Oxidation was followed via the increase in absorbance at $420 \mathrm{~nm}\left(\varepsilon_{420}=36,000\right.$ $\left.\mathrm{M}^{-1} \cdot \mathrm{cm}^{-1}\right)$. One unit of enzyme activity is defined as the amount of enzyme oxidizing $1 \mathrm{mmol}$ of ABTS per minute. Manganesedependent peroxidase (EC 1.11.1.13) activity was assayed with phenol red as the substrate $\left(\varepsilon_{610}=4460 \mathrm{M}^{-1} \mathrm{~cm}^{-1}\right)$ according to Kuwahara et al. (13). The reaction mixture $(1 \mathrm{~mL})$ contained $500 \mu \mathrm{L}$ enzyme extract, $100 \mu \mathrm{L}$ phenol red solution $(1.0 \mathrm{~g} / \mathrm{L})$, $100 \mu \mathrm{L}$ sodium lactate $\mathrm{pH} 4.5(250 \mathrm{mmol} / \mathrm{L}), 200 \mu \mathrm{L}$ bovine serum albumin solution $(0.5 \%), 50 \mu \mathrm{L}$ manganese sulfate $(2 \mathrm{mmol} / \mathrm{L})$ and $50 \mu \mathrm{H} \mathrm{H}_{2} \mathrm{O}_{2}(2 \mathrm{mmol} / \mathrm{L})$ in sodium succinate buffer $\mathrm{pH} 4.5$ (20 $\mathrm{mmol} / \mathrm{L})$. One unit of enzyme activity is defined as the amount of enzyme oxidizing $1 \mu \mathrm{mol}$ of substrate per minute. A control sample was tested using all the method conditions without manganese in order to demonstrate the manganese-dependency of the peroxidase. Lignina peroxidase (EC 1.11.1.14) activity was determined by monitoring the oxidation of veratryl alcohol to veratraldehyde at $37^{\circ} \mathrm{C}$ as indicated by an increase in $\mathrm{A}_{310}(\varepsilon=$ $9300 \mathrm{M}^{-1} \mathrm{~cm}^{-1}$ ) following the methodology by Tien and Kirk (30). The reaction mixture $(2.5 \mathrm{~mL})$ contained $500 \mu \mathrm{L}$ enzyme extract, $500 \mu \mathrm{L} \mathrm{H}_{2} \mathrm{O}_{2}(2 \mathrm{mmol} / \mathrm{L}), 500 \mu \mathrm{L}$ veratryl alcohol solution $(10 \mathrm{mmol} / \mathrm{L})$ and $1.0 \mathrm{~mL}$ sodium tartarate buffer $\mathrm{pH} 3.0(10$ $\mathrm{mmol} / \mathrm{L})$. One unit of enzyme activity is defined as the amount of enzyme oxidizing $1 \mu \mathrm{mol}$ of substrate per minute. Temperature was held constant at $37^{\circ} \mathrm{C}$ to investigate optimal $\mathrm{pH}$, while the $\mathrm{pH}$ was held at 5.0 to determine the optimal temperature. Kinetic tests were carried out at $37^{\circ} \mathrm{C}$ and $\mathrm{pH} 5.0$, and were calculated based on a Lineweaver-Burk plot (17). The kinetic properties were obtained in the stationary state by non-linear regression using Enzifitter (16) software.

L. sordida was cultivated for 57 days without shaking in the dark. In the early stages of growth, mycelia were white, but turned purple with the time. Laccase and manganese peroxidase activities were detected (Fig. 1), but no lignin peroxidase activity could be detected. The optimal temperature for laccase activity was $45^{\circ} \mathrm{C}$. This is in agreement with other research findings. Laccase from Phellinus ribis, for instance, reached highest activity at $50^{\circ} \mathrm{C}(20)$, and laccase from Pycnoporus cinnabarinus presented maximum stability below $50^{\circ} \mathrm{C}(7)$. L. sordida laccase presented highest activity at $\mathrm{pH} 3.5$, with a second activity peak at $\mathrm{pH}$ 6.0. These data are consistent with other studies showing optima $\mathrm{pH}$ values for other fungal species, like Pycnoporus cinnabarinus ( $\mathrm{pH} 4.0)(7)$, Lentinula edodes $(\mathrm{pH}$ 4.0) (5) and Coprinus cinereus (4.0) (25). The two activity peaks detected suggest the presence of an isozyme or indicate that this laccase presents two distinct $\mathrm{pH}$ optima, like observed in Agaricus bisporus (32) and Monocillium saxena (28). No laccase activity was detected at $\mathrm{pH}$ values higher than 6.5 , which is in

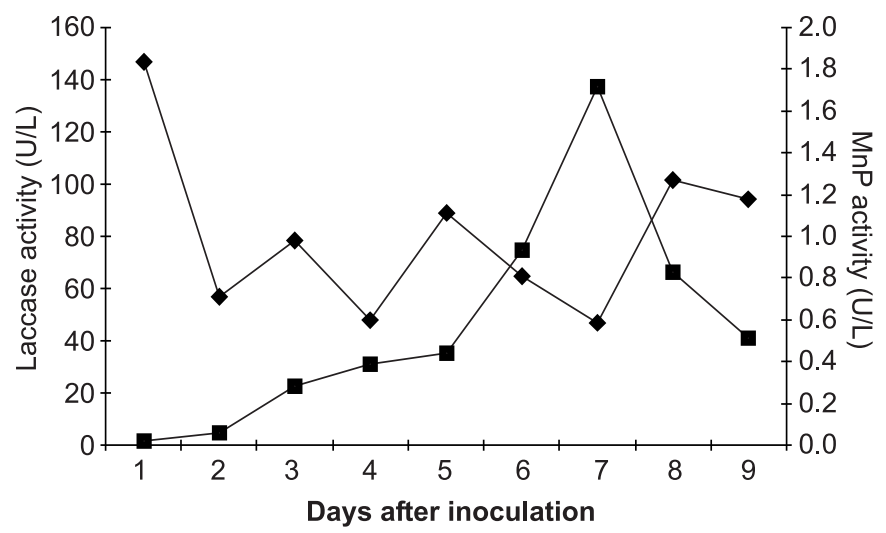

Figure 1. Time course of laccase ( $\square$ ) and manganese peroxidase $(\diamond)$ production by L. sordida at $25^{\circ} \mathrm{C}$ and $\mathrm{pH} 5.5$ under static cultivation.

agreement with findings for other fungal species, such as $L$. edodes (5,33). The $\mathrm{Km}_{\text {app }}$ was $101.6 \mu \mathrm{M}$ and $\mathrm{Vmax}_{\text {app }}$ was 0.84 $\mu \mathrm{M} . \mathrm{s}^{-1}$. Similar values were found in other fungal laccases $(11,20,24,25)$. It can be observed in Fig. 1 that laccase activity peaked at day $42(137 \mathrm{U} / \mathrm{L})$, and then started to decrease, indicating that the culture medium used was efficient in inducing laccase activity. It is known, however, that the activity profile can be altered by varying carbon and nitrogen sources. Galhaup et al. (8) investigated the effect of carbon sources on laccase production by Trametes pubescens and observed peaks of 5 and $10 \mathrm{U} / \mathrm{mL}$ when cultivated with $\alpha$-cellulose and lactose, respectively. Addition of glucose and frutose stimulated laccase activity, generating values as high as $60 \mathrm{U} / \mathrm{mL}$. Some species, like the well-studied Phanerochaete chrysosporium, present laccase activity only when nitrogen concentration falls to limiting levels $(10,12,15)$. On the other hand, L. edodes exhibits decreasing laccase activity following the depletion of nitrogen $(3,15)$. The culture media used in the present study was efficient to stimulate laccase activity in $L$. sordida with the nitrogen sources used ammonium phosphate $(0.15 \mathrm{~g} / \mathrm{L})$, yeast extract $(0.1 \mathrm{~g} / \mathrm{L})$ and ammonium molibdate $(0.011 \mathrm{~g} / \mathrm{L})$. We have reported for the first time laccase activity of $L$. sordida, a fungal species about which little information is available. Laccase is a very important enzyme, with many applications, and the search for new laccase sources is important given the large quantities necessary for all its potential uses.

\section{RESUMO}

\section{Produção de lacase por Lepista sordida}

Uma lacase de Lepista sordida foi caracterizada. O fungo produziu lacase e manganês peroxidase em meio líquido com fosfato de amônio, extrato de levedura e molibdato de amônio 
como fontes de nitrogênio 3 dias após a inoculação. Temperatura e pH ótimos para lacase foram $45^{\circ} \mathrm{Ce} 3,5$, respectivamente.

Palavras-chave: Lepista sordida, lacase, enzima

\section{REFERENCES}

1. Bauer C.G.; Kuehn, A.; Gajovic, N.; Skorobogatko, O.; Holt, P.J.; Bruce, N.C.; Makower, A.; Lowe, C.R.; Scheller, F.W. New enzyme sensors for morphine and codeine based on morphine dehydrogenase and laccase. Fresenius J. Anal. Chem., 364:179-183, 1999.

2. Bourbonnais, R.; Paice, M.G. Enzymatic delignification of Kraft pulp using laccase and a mediator. Tappi J., 79:199-204, 1996.

3. Buswell, J.A.; Cai, Y.; Chang, S.T. Effect of nutrient nitrogen and manganese on manganese peroxidase and laccase production by Lentinula (Lentinus) edodes. FEMS Microbiol. Lett. 128:81-88, 1995.

4. Crecchio, C.; Ruggiero, C.; Pizzigallo, M.D.R. Polyphenoloxidases immobilized in organic gels, Properties and applications in the detoxification of aromatic compounds. Biotechnol. Bioeng. 48:585591,1995

5. D'Annibale, A.; Stazi, S.R.; Vinciguerra, V.; Di Mattia, E.; Sermanni, G.G. Characterization of immobilized laccase from Lentinula edodes and its use in olive-mill wastewater treatment. Process Biochem. 34:697-706, 1999

6. Dean, J.F.D.; LaFayette, P.R.; Rugh, C.; Tristam, A.H.; Hoopes, J.T.; Eriksson, K.-E.L.; Merkle, S.A. Laccases associated with lignifying vascular tissues. In: Lignin and Lignin Biosynthesis ACS Symposium Series 697, American Chemical Society, Washington, DC, 1998, 96.

7. Eggert, C.; Temp, U.; Eriksson, K.-E.L. The ligninolytic system of the white rot fungus Pycnoporus cinnabarinus: Purification and characterization of the laccase. Appl. Envir. Microbiol., 62:1151$1158,1996$.

8. Galhaup, C.; Wagner, H.: Hinterstoisser, B.; Haltrich, D. Increased production of laccase by the wood-degrading basidiomycete Trametes pubescens. Enzyme Microb. Technol., 30:529-536, 2002.

9. Gianfreda, L.; Xu, F.; Bollag, J.-M. Laccases, a useful group of oxidoreductive enzymes. Biorem. J., 3:1-25, 1999.

10. Gold, M.H.; Alic, M. Molecular biology of the lignin-degrading basidiomycete Phanerochaete chrysosporium. Microbiol. Rev., 57:605-622, 1993.

11. Heinzkill, M.; Bech, L.; Halkier, T.; Schneider, P.; Anke, T. Characterization of Laccases and Peroxidases from Wood-Rotting Fungi (Family Coprinaceae). Appl. Envir. Microbiol., 64(5):16011606, 1998.

12. Kersey, P.; Kirk, T.K.; Zeikus, J.G. Ligninolytic enzyme system of Phanerochaete chrysosporium, Synthesized in the absence of lignin in response to nitrogen starvation. J. Bacteriol., 135:791-797, 1978.

13. Kuwahara, M.; Glenn, J.K.; Morgan, M.A.; Gold, M.H. Separation and characterization of two extracellular $\mathrm{H}_{2} \mathrm{O}_{2}$-dependent oxidases from ligninolytic cultures of Phanerochaete chrysosporium. FEBS Let. 169:247-250, 1984.

14. Larsson, S.; Cassland, P.; Jonsson, L.J. Development of a Saccharomyces cerevisiae strain with enhanced resistance to phenolic fermentation inhibitors in lignocellulose hydrolysattes by heterologous expression of laccase. Appl. Envir. Microbiol., 67:11631170,2001
15. Leatham, G.F. The ligninolytic activities of Lentinula edodes and Phanerochaete chrysosporium. Appl. Microbiol. Biotechnol., 24:5158, 1986.

16. Leatherbarrow, R.J. Enziffiter manual. London, Biosoft., 1987. p.1342.

17. Lineweaver, H.; Burk, D. The determination of enzyme dissociation constants. J. Am. Chem. Soc., 235:658-660, 1934.

18. Mayer, A.M.; Staples, R.C. Laccase, new functions for an old enzyme. Phytochem. in press.

19. Mayer, A.M. Polyphenol oxidases in plants-recent progress. Phytochem., 26:11-20, 1987.

20. Min, K.-L.; Kim, Y.-H.; Kim, Y.W.; Jung, H.S.; Hah, Y.C. Characterization of a Novel Laccase Produced by the Wood-Rotting Fungus Phellinus ribis. Arch. Biochem. Biophys., 392(2):279-286, 2001.

21. Nyanhongo, G.S.; Gomes, J.; Gübitz, G.; Zvauya, R.; Read, J.S.; Steiner, W. Production of laccase by a newly isolated strains of Trametes modesta. Bioresour. Technol., 84:259-263, 2002.

22. Pezet, R.; Pont, V.; Hoang-Van, K. Enzymatic detoxication of stillbenes by Botrytis cinerea and inhibition by grape berries proanthrocyanidins. In: Recent Advances in Botrytis research. Pudoc Scientific, Wageningen, 1992, p.87-92.

23. Raghukumar, C. Fungi from marine habitats, an application in bioremediation. Mycol. Res., 104:1222-1226, 2000.

24. Robles, A.; Lucas, R.; Martínez-Cañamero, M.; Omar, N.B.; Pérez, R.; Gálvez A. Characterization of laccase activity produced by the hyphomycete Chalara (syn. Thielaviopsis paradoxa CH32). Enzyme Microb. Technol., 31:516-522, 2002.

25. Schneider, P.; Caspersen, M.B.; Mondorf, K.; Halkier, T.; Skov, L.K Østergaard, P.R.; Brown, K.M.; Brown, S.H.; Xu, F. Characterization of a Coprinus cinereus laccase. Enzyme Microb. Technol., 25:502508,1999

26. Servili, M.; DeStefano, G.; Piacquadio, P.; Sciancalepore, V. A novel method for removing phenols from grape must. Am. J. Enol. Vitic., 51:357-361, 2000 .

27. Soares, G.M.B.; Costa, F.M.; Amorim, M.T.P. Decolorization of an antrhaquinone-type dye using a laccase formulation. Bioresour. Technol., 79:171-177, 2001

28. Thakker, G.; Evans, C.S.; Rao, K.K. Purification and characterization of laccase from Monocillium indicum Saxena. Microbiol. Biotechnol., 37:321-323, 1992.

29. Thurston, C.F. The structure and function of fungal laccases. Microbiol., 140: 19-26, 1994.

30. Tien, M.; Kirk, T.K. Lignin-degrading enzyme from Phanerochaete chrysosporium purification, characterization, and catalytic properties of a unique $\mathrm{H}_{2} \mathrm{O}_{2}$-requiring oxygenase. Proc. Natl. Acad. Sci., 81:22802284,1984

31. Tsai, H.F.; Wheeler, M.H.; Chang, Y.C.; Kwon, C.K.J. A developmentally regulated gene cluster involved in conidial pigment biosynthesis in Aspergillus fumigatus. J. Bacteriol., 181:6469-6477, 1999.

32. Wood, D.A. Production, purification and properties of extracellular laccase of Agaricus bisporus. J. Gen. Microbiol., 117:327-338, 1980.

33. $\mathrm{Xu}, \mathrm{F}$. Effect of redox potential and hydroxyde inhibition on the $\mathrm{pH}$ activity profile of fungal laccase. J. Biol. Chem., 272:924-928, 1997.

34. Zouari, N.; Romette, J.-L.; Thomas, D. Laccase electrode for the continuous-flow determination of phenolic compounds. Biotechnol. Tech., 8:503-508, 1994. 